\title{
Building Green Pathways Out of Poverty in the Oil Capital: Program Evaluation of Green Jobs Training Grant \\ Larry E. Hill ${ }^{*}$, Ph.D., M.S.W., Nory Angel' ${ }^{2}$, M.B.A.
}

${ }^{1 *}$ Assistant Professor, Prairie View A\&M University, College of Arts and Sciences, United States of America.

${ }^{2}$ Executive Director \& C.E.O., To Educate All Children (TEACH), Houston, Texas.

\author{
Article Details \\ Article Type: Research Article \\ Received date: $11^{\text {th }}$ February, 2020 \\ Accepted date: $24^{\text {th }}$ February, 2020 \\ Published date: $26^{\text {th }}$ February, 2020
}

"Corresponding Author: Larry E. Hill, Assistant Professor, Prairie View A\&M University, College of Arts and Sciences, United States of America. E-mail: lahill@pvamu.edu

Citation: Hill, L.E., Angel, N. (2020). Building Green Pathways Out of Poverty in the Oil Capital: Program Evaluation of Green Jobs Training Grant. J Ment Health Soc Behav 2(1):113. https://doi.org/10.33790/jmhsb1100113

Copyright: $\mathbb{C} 2020$, This is an open-access article distributed under the terms of the Creative Commons Attribution License 4.0, which permits unrestricted use, distribution, and reproduction in any medium, provided the original author and source are credited.

\begin{abstract}
s
This manuscript is a preliminary explorative study of a Department of Labor Pathways Out of Poverty Green Jobs Training program in Houston, Texas. Administrative data from clients $(\mathrm{n}=177)$ attending the program between June 2010 and April 2011 were analyzed. Our preliminary findings revealed three variables to independently predict employment in a green job in the final multivariate logistic regression model. Those who completed the solar power installation training $(\mathrm{AOR}=7.19, \mathrm{CI}=1.89,27.34)$ and business etiquette training $(\mathrm{AOR}=3.40 ; \mathrm{CI}=1.56,7.41)$ were significantly more likely to have a green job than those who did not complete that particular training. Interestingly, African Americans were significantly less likely to be employed in green jobs than other ethnicities $(\mathrm{AOR}=0.47$; $\mathrm{CI}=$ $0.23,0.98)$. Results also indicated that over half of the green jobs paid between $\$ 12.00$ and $\$ 33.00$ per hour. Overall, the manuscript provides preliminary data to explore effective program components to providing the Pathways Out of Poverty Green Jobs Training program. Further exploration is needed.
\end{abstract}

Keywords: Poverty, Green Jobs, Program, Training, Data Collection and Research

\section{Introduction}

Researchers have yet to determine the most effective way to link the emerging Green-Collar Economy to minority communities those with the highest unemployment, lowest wages, and arguably are the most marginalized from career-track positions. Such research is important in light of financial investments by the Department of Labor and private foundations to help engage low-income minority communities in green job training programs. Available academic literature has only distal relevance to this issue [1] or is limited to in-depth case studies [2] and white papers [3, 4]. Popularity has risen considerably during President Barack Obama's administration as evidenced by Pierce's [5] analysis revealing an almost 80 -fold increase in the number of internet articles with the term "green jobs" between January 2007 and January 2009. Yet, popularity is not equivalent to program effectiveness. The following preliminary report is the first attempt to explore predictors of success for a green job training program specifically targeted towards low-income, minority communities.

\section{Double Digit Unemployment}

Americans are experiencing high unemployment rates and difficulty re-entering the workforce [6,7]. African Americans and Latinos experience these issues at disproportionately higher rates than Caucasian. The last four decades have been marked with double digit national unemployment rates among African Americans and Latinos (BLS, 2010). Caucasians never reached double digit rates during this same period-even in the current economic crisis. National unemployment for African Americans and Latinos peaked at $19.5 \%$ and $13.8 \%$ during the early 1980 's, respectively. As of January 2011, double digit rates still remain high for African Americans and Latinos, at $15.7 \%$ and $11.9 \%$, respectively [8]. Caucasian rates were considerably lower at $8 \%$ for the same period.

\section{Green New Deal and Old New Deal}

The Green Collar Economy, America's emerging economic movement, may provide opportunities for real economic growth for those who take advantage of its opportunities. Van Jones, co-author of The Green Collar Economy: One Solution Can Fix Our Two Biggest Problems [9] and former Green Jobs Czar is one of many who advocated for the investment of government monies to create a new low- and medium-skill workforce. They successfully advocated for a Green New Deal to be inserted into the $\$ 786$ billion American Recovery and Reinvestment Act of 2009 (ARRA). Jones asserts:

"We need an entire suite of programs-intelligently coordinated. We need a complete set of policies and programs that would accelerate a market-led transition to a cleaner, greener, and more just economy - creating jobs, renewing hope, and strengthening community in the process. In other words, the time has come for a "new" New Deal. And this time it should be a green one. (2008, pg. 86-87).

ARRA funding in the amount of $\$ 117$ billion (12\% of total funding) was allocated to advance this emerging economy [10]. The set of Green New Deal action items were designed to concurrently solve socio-economic inequality and environmental issues. Global support followed as governments fought to stimulate their spiraling economies in the 2008-2009 global recession. Countries allocated approximately \$445 US billion for green investments with China's \$201 US billion leading the way.

This Green New Deal was a sequel to President Franklin Delano Roosevelt's New Deal; an innovative monetary policy that successfully reinvigorated and pulled the United States out of the Great Depression. New Deal programs such as the Tennessee Valley Authority and Works Progress Administration, and Civilian Conservation Corps (CCC) successfully created jobs for Americans after a sharp increase in national unemployment from 3.3\% in 1929 to $24.9 \%$ in 1933 (BLS, 2010). The latter was pivotal in employing approximately 2.5 million young men between 1933 and 1942 in a wide range of conservation jobs such as forestry, soil erosion prevention, 
reforestation, flood control, trail creation, and pest control while simultaneously providing them with vocational, literacy, and life skills education $[11,12]$.

In some areas of the country, minorities were employed by the $\mathrm{CCC}$ at disproportionate rates, received less pay, and contended with institutionalized racism, discrimination, and limited career tracks even from those who created the program. A historical review revealed that CCC Director Robert Fechner was supportive of helping people of color enroll into the program, but against their placement in particular supervisory positions [13]. We find handwritten evidence of this in a letter from President Roosevelt to Fechner where FDR wrote:

"In the CCC Camps, where the boys are colored, in the Park Service work, please try to put in colored foremen, not of course in technical work but in the ordinary manual work" [14].

The prolonged effects of past discriminatory hiring practices all influenced the current economic situations of minority communities [15]. Iconic figures such as Cesear Chavez, Martin Luther King Jr., and W.E.B. DuBois sought to close disparity gaps through policy change, program planning, and social movements. Today, trends are increasing for people of color entering higher paid professions, yet disparities still persist. For example, median weekly incomes for Black, Hispanic, Asian, and White men employed in management, professional, and other related occupations was $\$ 899$, $\$ 985, \$ 1,211$, and $\$ 1,342$ respectively [16].

\section{Green Collar Jobs}

Up until now, little energy has been channeled into transforming the quality of jobs [17]. The green collar movement addresses this issue. A clear distinction is made between green jobs and green collar jobs. That is, not all of the 467 green jobs titles identified by Dierdoff and colleagues are green collar jobs. Advocacy organizations such as the Apollo Alliance, Center for American Progress, Green for All and Urban Agenda and many others are advocating for environmentally conscientious jobs to be accessible and to be able to move people out of poverty. These agencies collectively define a green collar job as:

"well-paid, career-track jobs that contribute directly to preserving or enhancing environmental quality. Like traditional blue-collar jobs, green-collar jobs range from low-skill, entry-level positions to highskill, higher-paid jobs, and include opportunities for advancement in both skills and wages" [18].

Some potential green collar job sectors are: Building retrofits, green building construction, alternative energy vehicles, solar panel installation, energy auditors, and weatherization of homes, recycling and repurposing centers, and sustainable manufacturing (see Table 1). An energy auditing company providing building owners with energy efficient strategies may help its clients reduce their carbon footprint by $40 \%$, but not provide their employees with an income large enough to support their family or provide them with opportunities to move up the "career ladder" [18]. Companies such as this may provide green jobs but has little to no impact on improving the socioeconomic conditions of their employees.

\begin{tabular}{|c|c|c|}
\hline Variables & $\mathbf{n}$ & $\begin{array}{l}\text { \% or } \\
\text { (Mean, SD) }\end{array}$ \\
\hline \multicolumn{3}{|c|}{ DEMOGRAPHICS } \\
\hline \multicolumn{3}{|c|}{ City of Residence (n=177) } \\
\hline Houston & 167 & 94.4 \\
\hline Other & 10 & 5.6 \\
\hline \multicolumn{3}{|l|}{ Gender $(\mathrm{n}=177)$} \\
\hline Male & 163 & 92.1 \\
\hline Female & 14 & 7.9 \\
\hline \multicolumn{3}{|l|}{ Ethnicity $(\mathrm{n}=177)$} \\
\hline African American & 69 & 39 \\
\hline Hispanic & 88 & 49.7 \\
\hline White & 13 & 7.3 \\
\hline Other & 7 & 3.9 \\
\hline Age $(\mathrm{n}=177)$ & & $(34.33,11.00)$ \\
\hline $18-25$ & 54 & 30.5 \\
\hline $26-35$ & 42 & 23.7 \\
\hline $36-45$ & 48 & 27.1 \\
\hline 46 and over & 33 & 18.6 \\
\hline \multicolumn{3}{|c|}{ Veteran Status $(\mathrm{n}=138)$} \\
\hline No & 124 & 89.9 \\
\hline Yes & 14 & 10.1 \\
\hline
\end{tabular}

\section{Green Jobs Training and Placement Program Model}

This manuscript will explore the Raquel Pinderhughes Green Jobs Training and Placement Program Model [19]. Pinderhughes and colleagues collected data in 2006-2007 through 1) in depth interviews representing 21 green businesses registered with City of Berkeley's Green Business Program that were providing employees with manual jobs in the green jobs sector; 2) interviews with City of Berkeley and Oakland staff; and 3) 36 individuals with an array of barriers to employment. The findings were then used to create a working intervention model that was championed by the Ella Baker Center for Human Rights' Green Jobs Training Campaign and Oakland Apollo Alliance to advocate for the City of Oakland to provide funding for 
green job training. Her research supported agencies advocating for the City of Oakland's Request for Proposals. The Oakland Green Jobs Training Corps was then awarded $\$ 250,000$ to execute the program as a demonstration project.

The Green Jobs Act of 2007, authored by former California Congresswoman Hilda Solis, provided significant momentum for the Green Collar Jobs Movement. As part of the larger Energy Independence and Security Act of 2007, signed by President Bush, included $\$ 125$ million for green jobs training programs, in which $\$ 25$ million was targeted toward low-income communities. This \$25 million funding stream was known as the Pathways Out of Poverty Demonstration Grants and was supported by organizations such as Center for American Progress, National Apollo Alliance, and the Ella Baker Center for Human Rights. The model also helped to shape the 2010 Department of Labor, Pathways Out of Poverty Grant, which was funded at $\$ 150$ million and authorized through ARRA. January 2010, Secretary of Labor, Hilda Solis, announced 38 grant awards to non-profit organizations, faith-based organizations, community colleges, and job training organizations in amounts ranging from $\$ 2.10$ million to $\$ 7.99$ million.

Pinderhughes proposed nine distinct program components for green job training and placement which "prepare men and women with barriers to employment to become job ready and obtain entrylevel green collar jobs" [19]. These include: 1) Target Population 2) Training 3) Internships 4) Case Management and Follow-up 5) Pathways to Employment \& Educational and Occupational Mobility 6) Employers 7) Green Business Council 8) Local Government 9) Community Involvement (see appendix for detailed description). The working intervention model suggests that programs focus on including low-income communities in recruitment efforts as they seek out 18-35 year old low-income clients to provide them with comprehensive training and classroom instruction. Such training may include job, life, and soft skills trainings. Classroom instruction should also include empirically based math, literacy, and environmental curriculums.

Of equal importance are organization's efforts to connect clients with green businesses that have job or internship opportunities. Successful programs build relationships with local employers, Green Business Councils, local governments, and low-income communities. The program capitalizes on these relationships to mobilize internship and on-the-job training opportunities for their clients. Throughout the program, case managers are providing family support services, counseling, and other activities necessary to remove barriers impeding client retention in the program. Case managers also conduct 2-6 month follow-up activities after clients receive their first green job. The ultimate goal is placement in a green collar job or assisting clients with entering onto pathways to employment, educational, or occupational upward mobility. This may include enrollment in adult education or college, ongoing enrollment in job placement services, on-the-job training opportunities, or union apprenticeship programs.

To date, no research exists which evaluates the effectiveness of the processes or outcomes associated with the model or the green jobs training initiative. The purpose of this program evaluation is to examine the preliminary implementation of a Department of Labor funded green jobs training program; which is specifically designed to lift families out of poverty. More specifically, the Pinderhughes Green Jobs Training Model is explored for main predictors associated with the primary goal of helping impoverished individuals enter onto pathways to employment, educational, and occupational mobility. Therefore, the following explorative research question will guide the program evaluation:

What are the main predictors of low-income clients' employment after being enrolled in an American Recovery and Reinvestment Act (ARRA) funded Green Jobs Training program?

\section{Methods \\ Program Description}

In January 2009, the Department of Labor awarded SER Jobs for Progress of the Texas Gulf Coast Inc. \$3.1 million over 3 years to engage, train, and help employ low-income communities in the emerging Green Collar Economy under the Pathways Out of Poverty Grant. This represents one of 38 awards. The agency "will recruit, assess, and enroll individuals from impoverished urban neighborhoods in Houston, Texas. The participants will train for employable proficiency and apprenticeship admission in the core competencies for construction and building trades required by the National Center for Construction Education and Research (NCCER). Upon successful completion of pre-apprenticeship training, participants will receive occupational training in one of three occupations: 1) Weatherization Worker Technician coupled with Green Advantage certification; 2) Solar Panel Installer; or 3) HERS Energy Rater/ Whole House Diagnostic.

The participants will subsequently receive on-the-job training and full-time employment through the grantee's placement and retention service and support services through the grantee's partnering organizations. They will come from the following Public Micro Data Areas (PUMA) where poverty rates were above 15\% (e.g. 04601, 04602, 04603, 04606, 04608, 04610, 04611, 04625). Key partners include: Houston Works USA, Houston Community College, US Green Building Council, Greater East End Management District, American Federation of Labor and Congress of Industrial Organizations (AFL-CIO), Association of General Contractors, and Standard Renewable Energy. SER Jobs for Progress of the Texas Gulf Coast started enrolling participants into their Green Jobs Training program in the second quarter of 2010 and has experienced a steadily increasing enrollment.

\section{Data Collection}

All data collection procedures were approved by the Prairie View A\&M University Institutional Review Board. Administrative data from SER Jobs for Progress of the Texas Gulf Coast was collected which represents client data between January 2009 and January 2011. Case managers, counselors, and other program staff collect data during two main points 1) during the intake assessment and 2) during follow-up services. Variables relevant to the model were selected from the agency database by the Principal Investigator. Several variables not in the agency electronic database were extracted from client files.

\section{Independent Variables}

Demographics: (e.g. age, gender, ethnicity, barriers to employment, level of education, criminal background, government assistance, labor market experience) all measured in rank order or dichotomously.

Training: NCCER pre-apprenticeship training, weatherization, heating ventilation and air conditioning, Home Energy Rating Systems, solar panel installation, business etiquette) measured by " $0=$ did not complete, $1=$ complete"

Internships: (participation in trial period, participation in an internship), $0=$ "did not complete", $1=$ "complete"

\section{Outcome Variables}

Program Success: (employment in a green job) as measured by " $0=$ no $1=$ yes"

\section{Program Participants}

A total of 177 cases were analyzed. A vast majority of the program participants resided in impoverished areas of Houston (94.4\%). They were male $(92.1 \%)$, non-veterans $(89.9 \%)$, with ages ranging from 18 to 59 years old $(\mathrm{M}=34.33, \mathrm{SD}=11.00)$. There were also more Latinos (49.7\%) than African Americans (39.0\%). Over 90\% were not currently working at the time of the initial assessment (see Table 1). 
Program participants had household income levels that were 200\% below the Federal Poverty Threshold. Over $40 \%$ were receiving some form of public assistance such as unemployment assistance, food stamps, SSI, TANP, etc. Program participants also had a number of barriers to employment including high school education or less
(87.1\%), being a person of color $(92.7 \%)$, were laid off from work (59.3\%), limited transportation (39.6\%), no driver's license $(21.9 \%)$, low level of computer skills $(50.0 \%)$ and had disabilities (13\%). One fourth had non-violent felony backgrounds (19.9\%), such as drug trafficking and drug possession charges (see Table 2).

\begin{tabular}{|c|c|c|}
\hline Variables & n & $\%$ \\
\hline \multicolumn{3}{|l|}{ Education $(n=147)$} \\
\hline Less than High School & 7 & 4.8 \\
\hline GED & 39 & 26.5 \\
\hline High school diploma & 82 & 55.8 \\
\hline Vocational Training & 8 & 5.4 \\
\hline $\mathrm{BA} / \mathrm{BS}$ & 8 & 5.4 \\
\hline Post Graduate & 3 & 2 \\
\hline \multicolumn{3}{|c|}{ Criminal Background $(\mathrm{n}=136)$} \\
\hline None & 78 & 57.4 \\
\hline Misdemeanor & 31 & 22.8 \\
\hline Felony & 27 & 19.9 \\
\hline \multicolumn{3}{|c|}{ Currently receiving public assistance $(\mathrm{n}=137)$} \\
\hline No & 79 & 57.7 \\
\hline Yes & 58 & 42.3 \\
\hline \multicolumn{3}{|c|}{ Laid off from work $(n=135)$} \\
\hline No & 55 & 40.7 \\
\hline Yes & 80 & 59.3 \\
\hline \multicolumn{3}{|l|}{ Transportation $(n=144)$} \\
\hline Metro Bus & 34 & 23.6 \\
\hline Share a family vehicle & 21 & 14.6 \\
\hline Carpool & 2 & 1.4 \\
\hline Own a car & 84 & 58.3 \\
\hline Other & 3 & 2.1 \\
\hline \multicolumn{3}{|l|}{ Disabilities $(n=123)$} \\
\hline No & 107 & 87 \\
\hline Yes & 16 & 13 \\
\hline \multicolumn{3}{|c|}{ Level of computer skills $(n=128)$} \\
\hline None & 7 & 5.4 \\
\hline Basic & 58 & 45.3 \\
\hline Intermediate & 36 & 28.1 \\
\hline Advanced & 27 & 21 \\
\hline
\end{tabular}

\section{Data Analysis}

The Statistical Packages for Social Sciences (SPSS v.19) was used to analyze the quantitative data. Univariate analyses were conducted on each variable to provide descriptive statistics. Chi-square and t-tests were conducted on each indicator variable and outcome variables. Only statistically significant variables $(\mathrm{p} .<0.25)$ from the bi-variate analyses will be included in the multivariate model [20]. Criterion for inclusion of indicator variables in the final multivariate analysis was set at $\mathrm{p} .<0.10$. The last step was to conduct the multivariate logistic regression analysis to determine statistically significant variables associated with program outcomes.

\section{Results}

\section{Pre-Apprenticeship Training}

Each program participant must complete the CORE National Center for Construction Education and Research (NCCER) curriculum to enter the next set of training classes. There are eight separate training components which are completed within a 2-week period and last 8 hours a day. Income eligible participants receive gas cards \$25$\$ 50$ every week for support. Program component cover 1) Safety 2) Construction Math 3) Hand Tools 4) Construction Drawings 5) Communication Skills 6) Employability Skills 7) Material Handling and 8) Your role in the Green Environment. Some participants $(18.6 \%)$ dropped out of the pre-apprenticeship program or were currently in the program at the time the database was extracted.

\section{Green Collar Job Training}

Program participants indicated their areas of interest in different types of job training courses prior to entry into the program. Of those who responded, the most common response was Green Construction 
Training (65.7\%), HVAC (63.6\%), Weatherization (55.8\%), Solar/ Thermal (40.7\%), and HERS (26.6\%) (see Table 3). Program participants complete various introductory trainings offered by SER Jobs for Progress, for-profit companies and local community colleges. They completed weatherization (43.5\%), HVAC (29.9\%), HERS (43.5\%), Solar (29.9\%), and THP Solar (1.7\%). Five participated in paid on the job trainings at energy auditing and construction companies that partner with SER Jobs for Progress of the Texas Gulf Coast. Other supplementary trainings were also offered to help those who want to establish businesses in the Green Collar Economy. These were business etiquette (14.8\%) courses.

\begin{tabular}{|c|c|c|}
\hline Variables & $\mathbf{n}$ & $\%$ \\
\hline \multicolumn{3}{|c|}{ Interest in Training Program Types } \\
\hline \multicolumn{3}{|c|}{ Weatherization $(\mathrm{n}=138)$} \\
\hline No & 61 & 44.2 \\
\hline Yes & 77 & 55.8 \\
\hline \multicolumn{3}{|c|}{ Solar/Thermal Power $(n=140)$} \\
\hline No & 83 & 59.3 \\
\hline Yes & 57 & 40.7 \\
\hline \multicolumn{3}{|c|}{ Heating Ventilation and Air Conditioning $(\mathrm{n}=140)$} \\
\hline No & 51 & 36.4 \\
\hline Yes & 89 & 63.6 \\
\hline \multicolumn{3}{|c|}{ Job Readiness $(\mathrm{n}=140)$} \\
\hline No & 125 & 89.3 \\
\hline Yes & 15 & 10.7 \\
\hline \multicolumn{3}{|c|}{ Green Construction Skills $(\mathrm{n}=140)$} \\
\hline No & 48 & 34.3 \\
\hline Yes & 92 & 65.7 \\
\hline \multicolumn{3}{|c|}{ Undecided $(n=140)$} \\
\hline No & 125 & 89.3 \\
\hline Yes & 15 & 10.7 \\
\hline \multicolumn{3}{|c|}{ Home Energy Rating Systems $(\mathrm{n}=139)$} \\
\hline No & 102 & 73.4 \\
\hline Yes & 37 & 26.6 \\
\hline
\end{tabular}

The preliminary data suggest that the Pathways Out of Poverty Green Jobs Training in Houston, Texas was successful is placing 34 of $177(19.2 \%)$ of their program participants in Green Jobs. Many of these green jobs could be considered green collar jobs based on the hourly wage. That is, $53.1 \%$ of the hourly wages were between $\$ 12.00$ and $\$ 33.00 / \mathrm{hr}$. Some examples were Harris County Environmental Health Services, energy auditing firms, and HVAC businesses. Sixteen of the 34 salaries either remained the same or increased.

\section{Work Experience}

Almost $60 \%$ had more than 2 years of construction previous construction experience and ranged from several months to 30 years. Participants most recent job's average starting hourly average was equivalent to $\$ 12.31(\mathrm{SD}=\$ 5.61)$, ended at $\$ 13.65(\mathrm{SD}=\$ 5.87)$ ranging from minimum wage to over $\$ 33 /$ hour.

The starting and ending median hourly wage of their most recent job was $\$ 10 / \mathrm{hr}$ and $\$ 12 / \mathrm{hr}$, respectively; ranging from $\$ 5.15$ to $\$ 36 /$ hr. The median number of months participants had at their last job was 8 months. Interestingly, $37.7 \%$ were employed at their last job for one year or less. This is relatively common amongst those in the construction industries. This demonstrates a lack of stable employment.

\section{Predicting Green Jobs}

Univariate logistic regression analyses were conducted between each predictor and the desired outcome of obtaining a green job after the pathways out of poverty program (see Table 4).

Variables with total responses below 145 were excluded from the univariate analysis and final multivariate analysis. Odds ratios (OR) were obtained from each analysis with the $75 \%$ confidence interval (CI). Variables meeting the $\mathrm{p} .<0.25$ significance level were included in the final multivariate analysis. An adjusted odds ratio (AOR) was $90 \%$ CI levels were reported for the final model.

The univariate analyses revealed that African American were significantly less likely than other ethnic groups to be employed in green jobs, whereas Latinos were significantly more likely than other ethnic groups. The preliminary results revealed a trend that those with a high school education or less were significantly more likely to obtain a Green Collar Job. Some Pathways Out of Poverty program components were significantly more likely to predict employment in a green job. For instance, those who completed the Weatherization, Solar Panel Installation, On the Job Training, or Business Etiquette courses were significantly more likely to be employed in a green job. Variables such as gender, criminal background, being Caucasian were all not statistically significant and were not included in the final analysis.

The final multivariate analysis was conducted with variables were statistically significant at p. $<0.25$. The forward stepwise multiple logistic regression revealed three variables to independently predict employment in a green job. First, African Americans were significantly less likely to be employed in green jobs $(\mathrm{AOR}=0.47$; 


\begin{tabular}{|c|c|c|c|c|}
\hline Variables & $\mathrm{n}(\%)$ & $\begin{array}{l}\text { Employed in Green } \\
\text { Job (Row \%) }\end{array}$ & Odds Ratio $(75 \% \mathrm{CI})$ & $\mathrm{p}$. \\
\hline \multicolumn{5}{|l|}{ DEMOGRAPHICS } \\
\hline \multicolumn{5}{|l|}{ Gender } \\
\hline Male & $163(92.1)$ & 19 & \multirow[b]{2}{*}{$1.16(0.53,2.54)$} & \multirow[b]{2}{*}{0.83} \\
\hline Female & $14(7.9)$ & 21.4 & & \\
\hline \multicolumn{5}{|l|}{ African American } \\
\hline No & $108(61.0)$ & 79.7 & $0.50(0.31,0.81)$ & 0.1 \\
\hline Yes & $69(39.0)$ & 88.2 & & \\
\hline \multicolumn{5}{|l|}{ Caucasian } \\
\hline No & $164(92.7)$ & 18.9 & \multirow[t]{2}{*}{$1.29(0.58,2.84)$} & \multirow[t]{2}{*}{0.71} \\
\hline Yes & $13(7.3)$ & 23.1 & & \\
\hline \multicolumn{5}{|l|}{ Hispanic/Latino } \\
\hline No & $89(50.2)$ & 13.5 & \multirow[t]{2}{*}{$2.14(1.36,3.37)$} & \multirow[t]{2}{*}{0.06} \\
\hline Yes & $88(49.7)$ & 25 & & \\
\hline \multicolumn{5}{|l|}{ Age } \\
\hline $18-35$ years old & $81(45.8)$ & 21.9 & \multirow[t]{2}{*}{$0.82(0.67,1.00)$} & \multirow[t]{2}{*}{0.26} \\
\hline 36 years and older & $96(54.2)$ & 16 & & \\
\hline \multicolumn{5}{|l|}{ Education } \\
\hline High School/GED or Less & $19(11.8)$ & 16.9 & \multirow[t]{2}{*}{$3.66(0.47,28.75)$} & \multirow[t]{2}{*}{0.22} \\
\hline$>$ than High School & $142(88.2)$ & 5.3 & & \\
\hline \multicolumn{5}{|l|}{ Background } \\
\hline Clean/Misdemeanor & $129(72.9)$ & 17.8 & \multirow[t]{2}{*}{$1.55(0.94,2.56)$} & \multirow[t]{2}{*}{0.31} \\
\hline Felony & $32(18.1)$ & 12.5 & & \\
\hline \multicolumn{5}{|c|}{ PATHWAYS OUT OF POVERTY TRAININGS } \\
\hline \multicolumn{5}{|c|}{ CORE Training - Pre-apprenticeship } \\
\hline Did not complete & $32(18.2)$ & 42 & \multirow[t]{2}{*}{$1.91(0.62,5.85)$} & \multirow[t]{2}{*}{0.26} \\
\hline Completed & $144(81.8)$ & 26.5 & & \\
\hline Weatherization Training & & & & \\
\hline Did not complete & $100(56.8)$ & 40.6 & $1.86(0.87,3.95)$ & 0.11 \\
\hline Complete & $76(43.2)$ & 55.9 & & \\
\hline HVAC Training & & & & \\
\hline Did not complete & $124(70.0)$ & 20.2 & $0.81(0.35,1.88)$ & 0.62 \\
\hline Complete & $53(30.0)$ & 17 & & \\
\hline Home Energy Rating Systen & & & & \\
\hline Did not complete & $158(89.3)$ & 18.4 & $1.59(0.53,4.76)$ & 0.41 \\
\hline Complete & $19(10.7)$ & 26.3 & & \\
\hline Solar Panel Installation & & & & \\
\hline Did not complete & $169(96.0)$ & 2.1 & $6.22(1.32,29.26)$ & 0.02 \\
\hline Complete & $7(4.0)$ & 11.8 & & \\
\hline On the Job Training & & & & \\
\hline Did not complete & $172(97.7)$ & 2.1 & $2.92(0.47,18.18)$ & 0.26 \\
\hline Complete & $4(2.3)$ & 5.9 & & \\
\hline Business Etiquette & & & & \\
\hline Did not complete & $150(85.2)$ & 11.3 & $3.28(1.33,8.09)$ & 0.01 \\
\hline Complete & $26(14.8)$ & 29.4 & & \\
\hline
\end{tabular}

Table 4. Pathways out of poverty variables, odds ratios for employment in a green job $(n=177)$ 
$\mathrm{CI}=0.23,0.98) . \quad$ Second, those who completed the solar power installation training $(\mathrm{AOR}=7.19, \mathrm{CI}=1.89,27.34, \mathrm{p} .=.015)$ at the local community college were significantly more likely to be employed in green jobs. Program participants who completed the solar panel installation training were more than seven times as likely to have a green job as those who did not complete the training. Lastly, completing the business etiquette trainings $(\mathrm{AOR}=3.40 ; \mathrm{CI}=1.56$, 7.41) was a statistically significant predictor of having a green job.
Those who completed the business etiquette trainings were 3.4 times as likely to be employed in a green job. All other variables were not reliable predictors of our outcome. This is not to say the findings end here. That is, having certain barriers to employment such as gender, being 18-35 years old, having a criminal background were not predictors of employment which indicates open job opportunities for females, young adults, and those with a non-violent misdemeanor or felony background.

\begin{tabular}{|c|c|c|c|c|}
\hline Variables & $\mathrm{n}(\%)$ & Employed in Green Job (Row \%) & Odds Ratio $(90 \% \mathrm{CI})$ & p. \\
\hline \multicolumn{5}{|l|}{ African American } \\
\hline No & $107(60.8)$ & 23.1 & \multirow[t]{2}{*}{$0.47(0.23,0.98)$} & \multirow[t]{2}{*}{0.09} \\
\hline Yes & $69(39.2)$ & 13 & & \\
\hline \multicolumn{5}{|l|}{ Business Etiquette } \\
\hline Did not complete & $150(85.2)$ & 16 & \multirow[t]{2}{*}{$3.40(1.56,7.41)$} & \multirow[t]{2}{*}{0.1} \\
\hline Completed & $26(14.8)$ & 38.5 & & \\
\hline \multicolumn{5}{|c|}{ Solar Panel Installation } \\
\hline Did not complete & $169(96.0)$ & 17.6 & \multirow[t]{2}{*}{$7.19(1.89,27.34)$} & \multirow[t]{2}{*}{0.02} \\
\hline Completed & $7(4.0)$ & 57.1 & & \\
\hline
\end{tabular}

\section{Discussion}

This study is among the first to empirically explore the Pinderhughes model and the Pathways Out of Poverty Green Jobs Training program with multivariate analysis. These preliminary findings are timely given the unstable climate of government funding. For instance, in April 2011 President Barack Obama signed the federal budget which had the largest spending cuts in US history. These deep cuts came two years after President Obama began his presidency by signing ARRA, the largest spending bill in US history. This one-time stimulus package catalyzed the Green Collar Jobs movement with significant investments in alternative energy research, tax incentives for green building, weatherization of low-income homes, and green job training programs. The Pathways Out of Poverty program is a direct beneficiary of these tough economic times in the same manner that new infrastructure and social programs were beneficiaries of President Roosevelt's New Deal.

This preliminary study explored the POP program as delivered by SER Jobs for Progress of the Texas Gulf Coast Inc. More specifically, we conducted a multivariate analysis to identify the main predictors of low-income clients' employment after being enrolled in an American Recovery and Reinvestment Act (ARRA) funded Green Jobs Training program, which targeted impoverished communities. We found three statistically significant variables that predict program employment in green jobs after enrolling in the program. The data suggest that African Americans were less likely to be employed in green jobs than other ethnicities. That is, 9 (or $26.9 \%$ ) of the 34 people employed in Green Jobs were African American even though 39\% of the sample was African American. The findings are not uncommon to the employment literature yet are still troublesome. For example, unemployment remains highest for African Americans as compared to other ethnic groups [8]. Dr. Martin Luther King addresses the reasons and solution to this issue during a speech on Social Justice and the Emerging New Age at Western Michigan University in 1963. He suggests,

"I think we must honestly face a fact if one gets behind in a race, he must eternally remain behind or run faster than the man in front. You've got to give him the equipment to catch up. Now the fact is that the Negro has had 244 years of slavery in America and working without wages and then he's had a hundred years of segregation and mistreatment in generally. Now, he's faced with a very serious problem and that is that he is required to be as productive as people who have not had these conditions and the only thing that a society can do for individuals who have been deprived of something is to give them a little special treatment. Now you don't put anybody out of a job, but you just make it possible for the individuals who are behind to catch up" [21].

Dr. King states a need for the African American community to run faster and special effort needed to pull the ethnic group ahead. Program planners and advocates must capitalize on the opportunity to engage the African American community in the Green Collar Economy. This must be done with expediency on the part of the community, businesses, social service providers, and local government even within the higher education pipeline.

The second major predictor of obtaining a green job was completion of the solar power installation training at the local community college. Those who completed the solar power installation program were more than seven times as likely to be employed in green jobs as those who did not complete the program. The preliminary data suggests that the solar panel installation training program is a powerful program component in the Pathways Out of Poverty program. Additional research is needed after the funding cycle has ended to determine why this program component is such a strong predictor of success. For instance, there may be an increasing number of job opportunities for those with Solar Panel Installer Certifications in Texas. Other areas are experiencing this increasing trend. The American Solar Energy Society (2008) revealed a report on Colorado which contended that the renewable energy and energy efficiency industries "generated $\$ 10.3$ billion in sales and provided over 91,000 jobs" (2008, pg. 4) during 2007. Moreover, they projected that 16 to 37 million people could be employed in these two industries by 2030. If these projections are even close to being accurate, then individuals with the solar panel training will benefit as suggested by our findings. Non-profits in California are also experiencing success. According to [22] Wall Street Journal article "A New Gang Comes to Los Angeles: Solar-Panel Installers", a non-profit organization called Homeboy Industries partnered with East Los Angeles Skills Center 
to teach ex-gang members and those with criminal histories how to install solar panels. The partnership has been successful in providing clients well-paying job alternatives that range between $\$ 15$ and \$30 per hour. Our findings support this anecdotal evidence.

The third statistically significant predictor of obtaining a green job after enrolling in the pathways out of poverty program was completion of the business etiquette training program. Those who completed the program were almost three and a half times as likely to have a green job as those who did not complete the program. Additional research is needed to reveal how this is a significant predictor. The training involves creating a competitive professional resume, interviewing for higher paying positions, consultation with a job coach, and other soft skills trainings. A modest proportion $(38.5 \%)$ of those employed in green jobs completed the business etiquette courses.

Interestingly, the solar panel installation and business etiquette trainings were ranked relatively low in interest before entering training and low in completion compared to other training components. Program planners may consider ways to increase community interest in these trainings during recruiting efforts. These green jobs are well-paying jobs and offered opportunities for program participants to increase their hourly wage. Over half of the green jobs could be considered green collar jobs given the relatively competitive pay between $\$ 12.00$ and $\$ 33.00$ per hour. Almost half of the employment opportunities either remained the same or increased. Program planners may benefit from advocacy efforts to help businesses see the importance of providing not only green jobs but green collar jobs that offer a living wage and opportunities to move up a career track from low-skill and entry-level positions.

Portland, Oregon has implemented innovative ways to increase job quality through macro-level change efforts in policy and procurement which incentivizes businesses to pay employees wages at least $180 \%$ of the minimum wage and offer medical benefits [23]. Incentives are also offered for hiring employees directly from green job training programs that serve impoverished communities of color.

These efforts are consistent with the Pinderhughes model which suggests that Organizational Efforts to Mobilize Opportunities for their clients are as important as a client's individual effort to complete training.

Several weaknesses must be considered when interpreting our findings. First, this is a preliminary study of only one out of 38 Pathways Out of Poverty Green Jobs Trainings Programs. Several nuances exist that are specific to the context of SER Jobs for Progress of the Texas Gulf Coast Inc. Therefore, caution must be exercised when generalizing results to other programs. The job market influences an organization's ability to place their program participants as well as determine the type of training that is effective. For example, organizations in Nevada or California may have an increased number of solar panel jobs available as a direct result of their location of receiving a relatively large amount of sun. Areas in Oregon may be able to train and place a large number of trainees from completing the weatherization and energy auditing due to local government support for green building efforts. Another caution in interpreting the results of this study is that the Pathways Out of Poverty Green Jobs Training program is only $50 \%$ complete. Enrollment is steadily increasing with the organization's refined recruitment efforts.

The organization was experiencing an increase in job availability as the nation rebounds from the 2009-2010 global recession. This study is exploratory and uses administrative data. Reliability of the demographic data is dependent on the program participant's self-report. Completion of training is more reliable and verified by certificates and attendance by case managers. Lastly, the sample size is adequate for an analysis of main effects yet is not large enough to reliably assess interaction effects. Future research should include an increased sample size to test interaction effects between program components and demographics with the main outcome. We suspect that the numbers will be large enough toward the end of the threeyear funding period to conduct a multivariate analysis which includes both main and interaction effects.

\section{Conclusion}

The Green Collar Economy is an emerging economy with significant investments and the potential to lift impoverished communities out of poverty. Program planners and advocates can benefit from the empirical results of this study. The results of our study suggest that the Pinderhughes model may provide direction for enrolling and training impoverished communities with barriers to employment. More specifically, we found that African American were significantly less likely to be employed in green jobs. Further, solar panel installation training and business etiquette predicted employment in green jobs. Results also revealed increases in hourly wages, which may suggest these jobs are actually green collar jobs. Future efforts can focus on effective strategies to connect emerging green collar opportunities with green job training centers such as those supported by Federally supported programs. Social service and job placement agencies may benefit from brokering relationships between Green Business Councils chapters and new, emerging businesses. Projected job growth and ARRA funding may coincide to stimulate actual job growth in the near future. Therefore, the labor force, education systems, non-profit organizations, labor unions, and higher education systems must be ready to meet these demands.

Conflict of interest: The authors have declared no conflict of interest.

\section{References}

1. Scheuer, K., Dandridge, C., Richards, A. (2010). Tapping familiarity to increase the effectiveness of clean energy workforce training efforts: research results and recommended strategies. Summer Study on Energy Efficiency in Building 10 223-237.

2. Bellotti, J., Rosenberg, L., Sattar, S., Esposito, A. M., \& Ziegler, J. (2010). Reinvesting in America's youth: lessons from the 2009 recovery act summer youth employment initiative. Mathematica Policy Research, Inc. Mathematica Reference \# 06630.610.

3. Dierdoff, E. C., Norton, J. J., Drews, D. W., Kroustalis, C. M., Rivkin, D., \& Lewis, P. (2009). Greening of the world of work: Implications for $\mathrm{O}^{*} \mathrm{NET}$ soc and new and emerging occupations. Raleigh, NC: National Center for O*NET Development.

4. Pollin, R., \& Wicks-Lin, J. (2008, June). Job opportunities for the green economy. Political Economy Research Institute. University of Massachusetts, Amherst, (pp. 1-15).

5. Pierce, J. (2010). Jobs: What's green go to do with it? M.A. dissertation, Tufts University, United States -- Massachusetts. Retrieved January 20, 2011, from Dissertations \& Theses: Full Text.(Publication No. AAT 1481052).

6. Bureau of Labor Statistics. (2007). Metropolitan area employment and unemployment - November 2010. Washington, DC: U.S. Department of Labor, Bureau of Labor Statistics.

7. Spreen, T. L. (2010, October). Issues in labor statistics: Ranks of those unemployed for a year or more up sharply. U.S. Department of Labor, US Bureau of Labor Statistics. Summary 10-10.

8. Allegretto, S., Amerikaner, A., \& Pitts, S. (2010). Data brief: black employment and unemployment. Center for Labor Research and Education. University of California, Berkeley. $1-21$.

9. Jones, V., Conrad, A., \& Kennedy, R. F. (2008). The green-collar economy: How one solution can fix our two biggest problems. New York, NY: HarperOne. 
10. HSBC (2009). More green money on the table.

11. Maher, N. M. (2008). Nature's New Deal: The Civilian Conservation Corps and the Roots of the American Environmental Movement. Oxford University Press on Demand.

12. Speakman, J.M. (2006). Into the woods: the first year of the civilian conservation corps. Prologue: Quarterly of the National Archives and Records Administration, 38(3).

13. Dekhakhena, A. (2014). Blacks in the New Deal: The Shift from an Electoral Tradition and its Legacy. Anchor Academic Publishing

14. Roosevelt, F.D. (1935). FDR to Robert Fechner, 27 September, "CCC Negro Foreman" File, Box 700, General Correspondence of the Director, Record Group 35. National Archives, College Park, Maryland.

15. Pitts, S., \& Spriggs, W. (2008). Beyond the mountaintop: King's prescription for poverty black economists mark the 40th anniversary of the assignation. UC Berkeley Center for Labor Research and Education \& Howard University Department of Economics, (pp.1-24).

16. Bureau of Labor Statistics. (2007). Employed persons by detailed occupation and sex, 2007 Annual Averages. Washington, DC: U.S. Department of Labor, Bureau of Labor Statistics.
17. Pitts, S. (2004). Organize...to improve the quality of jobs in the black community. A report on jobs and activism in the African American community. UC Berkeley Center for Labor Research and Education, (pp.1-41).

18. Apollo Alliance and Green for All (2008). Green collar jobs in america's cities: building pathways out of poverty and careers in the clean energy economy.

19. Pinderhughes, R. (2007). Green collar jobs: An analysis of the capacity of green businesses to provide high quality jobs for men and women with barriers to employment, 1-91. Retrieved from http://bss.sfsu.edu/ raquelrp/documents/v13FullReport. pdf

20. Hosmer, D. W., \& Lemeshow, S. (2000). Model-building strategies and methods for logistic Applied Logistic Regression (2nd ed) pp. 91-143.

21. Martin Luther King (1963). Retrieved from http://www.wmich. edu/library/archives/mlk/q-a.html.

22. Jordan, M. (2009, February). A new gang comes to Los Angeles: Solar-panel installers. (Cover story). Wall Street Journal Eastern Edition, pp. A1-A9. Retrieved from Academic Search Complete database.

23. Ho, S. \& Hayes, J. (2011). High road outcomes in Portland's energy efficiency upgrade pilot. Green for All (pg. 1-19). 


\section{Journal of Mental Health and Social Behaviour Appendix A \\ PINDERHUGHES GREEN JOBS TRAINING and PLACE- MENT PROGRAM MODEL}

\section{CLIENT CHARACTERISTICS}

Target Population: 18-35 year old men and women with barriers to employment. This population includes men and women who do not have a high school degree, have been out of the labor market for a long time, were formerly incarcerated, and/or have limited labor market skills and experience.

\section{PROGRAM ACTIVITIES}

Training: This is an approximately 3-6 month training program that utilizes both training in the classroom and on-thejob training to provide clients with the following direct services: (1) initial assessment; (2) basic literacy skills (math, English, writing, computer, oral presentation, basic communication skills, etc.); (3) life skills and soft skills training; (4) financial management skills; (5) OSHA Safety Training Certification; (6) an environmental educational component; (7) basic vocational skills relevant to green collar workforce opportunities.

Internships: The internship component is designed to place job ready clients in local green collar jobs for a trial period of 2-6 months. Internship sites and placements will be identified by employers in the Green Business Council who will meet regularly to identify green collar internships as well as full-time jobs for job ready clients. The internships allow the employer and the client a trial period during which they can assess fit and capacity without committing to a full-time permanent position for the client. In the best case scenarios, clients who excel in their internships will be hired on as full-time workers.

Case Management and Follow Up: Each client will have access to case management and follow up services during the period in which they work as interns and for up to 6-12 months after they start their first job in a green business. Case management and follow up services are designed to help both the client and the employer.

\section{CLIENT OUTCOMES}

Pathways to Employment \& Educational and Occupational Mobility: Graduates of training programs that prepare people for green collar jobs will have access to multiple pathways to employment as well as to educational and occupational mobility. These pathways include: (1) ongoing on-the-job training opportunities in green businesses; (2) information about union apprenticeship programs, particularly electrical and construction; (3) access to higher education through adult schools, community colleges, and four year institutions; and (4) ongoing job placement services through employers in the Green Business Council.

\section{ORGANIZATIONAL EFFORTS to MOBILIZE OPPORTUNITIES}

Employers: To succeed, the program must have an involved, supportive, and enthusiastic group of green business employers who regularly communicate with the job training staff preparing program participants to enter the labor market. These employers will: (a) identify growing green economic sectors and opportunities; (b) identify training standards for specific green-collar jobs; (c) identify placement opportunities; (d) create internship opportunities for program participants; and (e) hire job ready applicants for entry level green collar jobs when there are job openings in their firms. They may also refer job ready applicants to firms outside of Berkeley.

Green Business Council: To develop and nurture relationships with employers, the Chamber of Commerce should convene a Green Business Council composed of the owners and managers of local green businesses in the private, non-profit, and public sectors that provide workers with green collar jobs.

Local Government: Government staff working on issues related to economic development, workforce development, and improvements in environmental quality should provide ongoing support to the green businesses that provide workers with green collar jobs. This can be accomplished in many ways, including: streamlining permitting processes for green businesses that provide green collar jobs in the city; utilizing procurement dollars and city contracts to support local green businesses; creating incentives for working with "first source" hiring policies; helping green businesses access tax credits; working with regional organizations that support job training programs.

Community Involvement: The program should involve members of Berkeley's low income communities in assisting with recruitment and retention of program applicants as well as supporting public and private sector initiatives to improve urban environmental quality and create green collar jobs. 